University of Nebraska - Lincoln

DigitalCommons@University of Nebraska - Lincoln

Agronomy \& Horticulture -- Faculty Publications

Agronomy and Horticulture Department

2008

\title{
Characterization of the folate salvage enzyme p-aminobenzoylglutamate hydrolase in plants
}

Gale G. Bozzo

University of Florida, gbozzo@uoguelph.ca

Gilles J. C. Basset

University of Nebraska-Lincoln, gbasset@ufl.edu

Valeria Naponelli

University of Florida, valina3@libero.it

Alexandre Noiriel

University of Florida, noiriel@ufl.edu

Jesse F. Gregory III

University of Florida, jfgy@ufl.edu

See next page for additional authors

Follow this and additional works at: https://digitalcommons.unl.edu/agronomyfacpub

Part of the Plant Sciences Commons

Bozzo, Gale G.; Basset, Gilles J. C.; Naponelli, Valeria; Noiriel, Alexandre; Gregory, Jesse F. III; and Hanson, Andrew D., "Characterization of the folate salvage enzyme $p$-aminobenzoylglutamate hydrolase in plants" (2008). Agronomy \& Horticulture -- Faculty Publications. 587.

https://digitalcommons.unl.edu/agronomyfacpub/587

This Article is brought to you for free and open access by the Agronomy and Horticulture Department at DigitalCommons@University of Nebraska - Lincoln. It has been accepted for inclusion in Agronomy \& Horticulture -Faculty Publications by an authorized administrator of DigitalCommons@University of Nebraska - Lincoln. 


\section{Authors}

Gale G. Bozzo, Gilles J. C. Basset, Valeria Naponelli, Alexandre Noiriel, Jesse F. Gregory III, and Andrew D. Hanson 


\title{
Characterization of the folate salvage enzyme p-aminobenzoylglutamate hydrolase in plants
}

\author{
Gale G. Bozzo, ${ }^{1}$ Gilles J.C. Basset, ${ }^{1}$ Valeria Naponelli, ${ }^{2}$ Alexandre Noiriel, ${ }^{1}$ \\ Jesse F. Gregory III, ${ }^{2}$ and Andrew D. Hanson ${ }^{1}$ \\ 1. Horticultural Sciences Department, University of Florida, Gainesville, FL 32611, USA \\ 2. Food Science and Human Nutrition Department, University of Florida, Gainesville, FL 32611, USA
}

Corresponding author - A. D. Hanson, tel 352 392-1928, fax 352 392-5653, email adha@mail.ifas.ufl.edu

\begin{abstract}
Folates break down in vivo to give pterin and $p$-aminobenzoylglutamate ( $p$ ABAGlu) fragments, the latter usually having a polyglutamyl tail. Pilot studies have shown that plants can hydrolyze $p$ ABAGlu and its polyglutamates to $p$-aminobenzoate, a folate biosynthesis precursor. The enzymatic basis of this hydrolysis was further investigated. $p$ ABAGlu hydrolase activity was found in all species and organs tested; activity levels implied that the proteins responsible are very rare. The activity was located in cytosol/vacuole and mitochondrial fractions of pea (Pisum sativum L.) leaves, and column chromatography of the activity from Arabidopsis tissues indicated at least three peaks. A major activity peak from Arabidopsis roots was purified 86-fold by a three-column procedure; activity loss during purification exceeded 95\%. Size exclusion chromatography gave a molecular mass of $\sim 200 \mathrm{kDa}$. Partially purified preparations showed a $\mathrm{pH}$ optimum near 7.5, a $K_{\mathrm{m}}$ value for $p$ ABAGlu of $370 \mu \mathrm{M}$, and activity against folic acid. Activity was relatively insensitive to thiol and serine reagents, but was strongly inhibited by 8-hydroxyquinoline-5-sulfonic acid and stimulated by $\mathrm{Mn}^{2+}$, pointing to a metalloenzyme. The Arabidopsis genome was searched for proteins similar to Pseudomonas carboxypeptidase G, which contains zinc and is the only enzyme yet confirmed to attack $p$ ABAGlu. The sole significant matches were auxin conjugate hydrolase family members and the At4g17830 protein. None was found to have significant $p$ ABAGlu hydrolase activity, suggesting that this activity resides in hitherto unrecognized enzymes. The finding that Arabidopsis has folate-hydrolyzing activity points to an enzymatic component of folate degradation in plants.
\end{abstract}

Keywords: Arabidopsis thaliana, Crucifereae, Folate salvage, Enzyme isolation and characterization, p-Aminobenzoylglutamate hydrolase, Folate hydrolase

\section{Introduction}

Tetrahydrofolate (THF) and its one-carbon derivatives (collectively termed folates) are essential cofactors for one-carbon transfer reactions. Folate molecules consist of pterin 4, $p$-aminobenzoate ( $p$ ABA 7), and glutamate 6 moieties, usually with a short, $\gamma$-linked polyglutamyl tail attached to the first glutamate (Figure 1a). Plants, fungi, and bacteria can synthesize folates but higher animals cannot and so need a dietary supply (Cossins, 2000; Scott et al., 2000).
Folates readily undergo spontaneous oxidative degradation in physiological conditions, yielding a pterin 4 and $p$-aminobenzoylglutamate 5 ( $p$ ABAGlu) or its polyglutamates (Figure 1a) (Suh et al., 2001). There is evidence that this breakdown process is particularly active in plants and that, in vivo, plants can hydrolyze the resulting $p$ ABAGlu 5 moieties to $p$ ABA 7 and glutamate 6 (Figure 1b) (Orsomando et al., 2006). Acting in concert with a reductive reaction that recycles the pterin fragment to a folate synthesis precursor, $p$ ABAGlu 5 hydrolysis enables complete salvage of folate $\mathbf{1}$ breakdown 


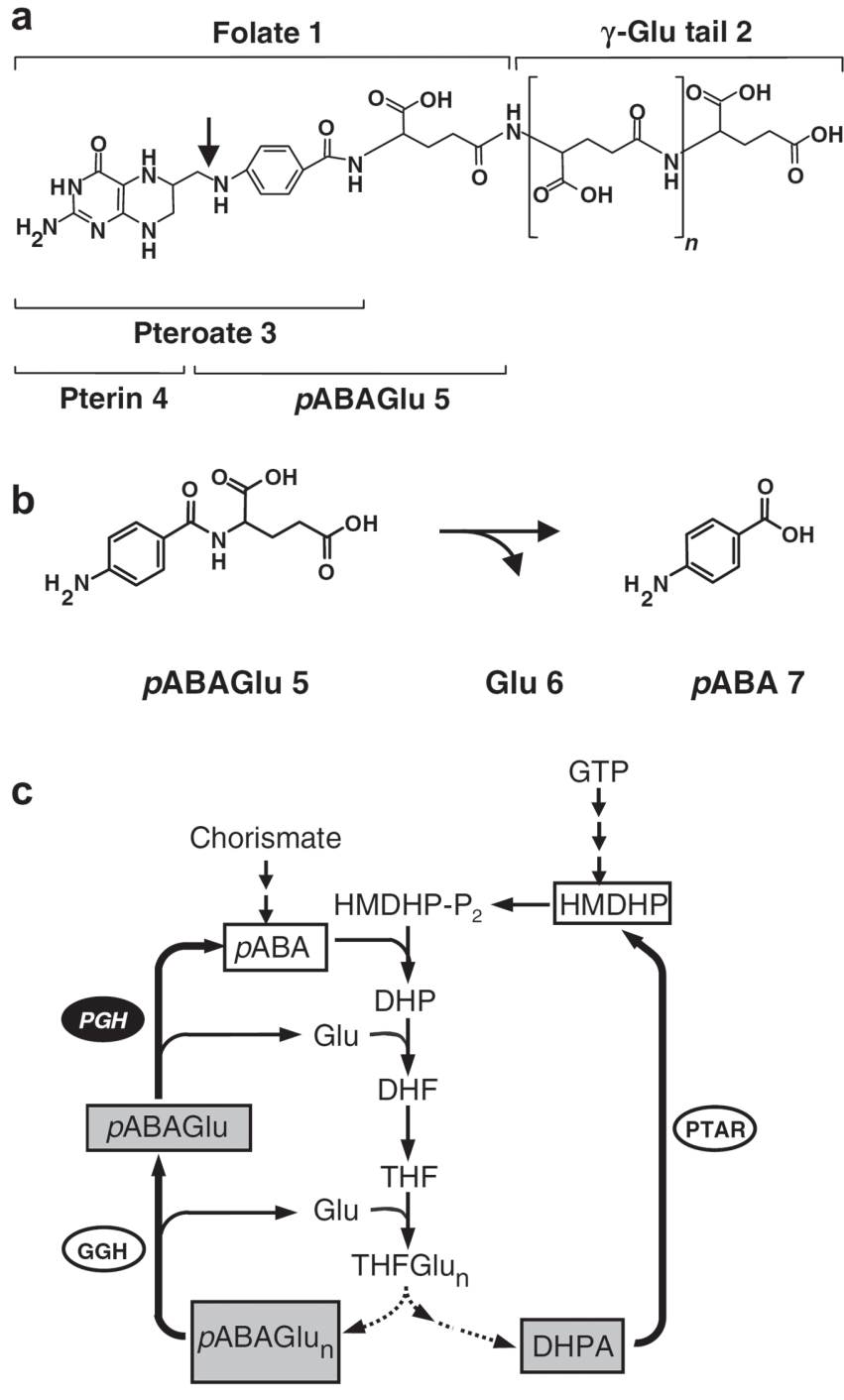

Figure 1. Structure of folates and hydrolysis of the $p$ ABAGlu moiety. (a) Tetrahydrofolate polyglutamate. Polyglutamyl tails of plant folates contain up to about six residues. Oxidative scission of the C9-N10 bond (arrow) yields pterin 4 and pABAGlu 5 fragments. (b) The $p$ ABAGlu 5 hydrolysis reaction. (c) Folate salvage reactions (broad arrows) in relation to folate biosynthesis. The pABAGlu 5 fragment from folate $\mathbf{1}$ cleavage (and its polyglutamyl 2 forms, $p$ ABAGlu $u_{n}$ ) can be recycled for use in folate synthesis after hydrolysis. Removal of the polyglutamyl tail by $\gamma$-glutamyl hydrolase (GGH) may be needed before $p$ ABAGlu hydrolase (PGH) acts. The pterin 4 fragment (dihydropterin-6-aldehyde, DHPA) from folate cleavage can be recycled to the folate synthesis intermediate hydroxymethyldihydropterin (HMDHP) by the action of pterin aldehyde reductase (PTAR). Other abbreviations: DHP, di-

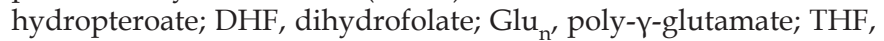
tetrahydrofolate; $-\mathrm{P}_{2}$, diphosphate.

products (Figure 1c). Although pABAGlu hydrolase (PGH) activity was detected in extracts of Arabidopsis and pea (Pisum sativum L.) leaves and of tomato (Lycopersicon esculentum Mill.) fruit, nothing further is known about this enzyme (Orsomando et al., 2006).

Nor, with one exception, is much known about pABAGlu-hydrolyzing enzymes from other organisms. The only well-characterized protein known to hydrolyze
pABAGlu 5 is carboxypeptidase G (CPG, EC 3.4.17.11), a di-zinc enzyme from Pseudomonas and other bacteria (McCullough et al., 1971; Albrecht et al., 1978; Sherwood et al., 1985). CPG also cleaves the $p$ ABA-glutamate bond in folates and folate analogs, releasing pteroate 3 and glutamate 6 fragments, and can remove the $\gamma$-glutamyl tail from polyglutamates by exopeptidase action. The Pseudomonas enzyme has been cloned (Minton et al., 1983). Other than CPG, there is genetic evidence that the Escherichia coli $a b g A$ and $a b g B$ gene products (which share weak sequence similarity with CPG) have PGH activity (Hussein et al., 1998; Carter et al., 2007). In addition, microorganisms and mammals are known to have an enzyme that releases pteroate from folate (Oe et al., 1983); this enzyme has neither been tested with $p$ ABAGlu 5 as substrate nor the encoding gene cloned.

After an initial survey of PGH activity in diverse plants, we determined the subcellular location of PGH activity in pea leaves and fractionated and characterized the activity from Arabidopsis leaves and roots. We also screened all Arabidopsis proteins with significant sequence similarity to CPG for PGH activity.

\section{Results and discussion}

\subsection{Survey of pABAGlu hydrolase activity}

Desalted extracts of various plant tissues were surveyed for PGH activity using a radioassay based on product separation by TLC (see Section 4, assay B). This assay, which uses a subsaturating concentration of $\left[{ }^{14} \mathrm{C}\right]$ pABAGlu $5(18-26 \mu \mathrm{M})$, is more sensitive and specific than that employed previously (Orsomando et al., 2006). PGH activity was readily detected in all tissues analyzed, which included those tested in a pilot study (Orsomando et al., 2006).

PGH activity was consistently higher in roots than in leaves, the difference ranging from 3- to 80-fold in Arabidopsis, pea, and maize (Zea mays L.) (Figure 2). It noteworthy that, for pea at least, this pattern is the inverse of that for folate biosynthesis enzymes, whose protein and RNA levels are about 5-fold lower in roots than in leaves (Jabrin et al., 2003). Roots from in vitro cultured Arabidopsis plantlets had less activity than those grown hydroponically but were easier to produce and had no microbial contaminants, and so were chosen for subsequent work on roots.

\subsection{Subcellular distribution of pABAGlu hydrolase activity}

PGH was localized by cellular fractionation and enzyme assay in pea leaves, which - while low in PGH activity - are the tissue of choice for obtaining high yields of intact organelles (Baldet et al., 1993) and have been much used in folate biochemistry (e.g., Chen et al., 1997; Jabrin et al., 2003). Marker enzyme assays confirmed that puri- 


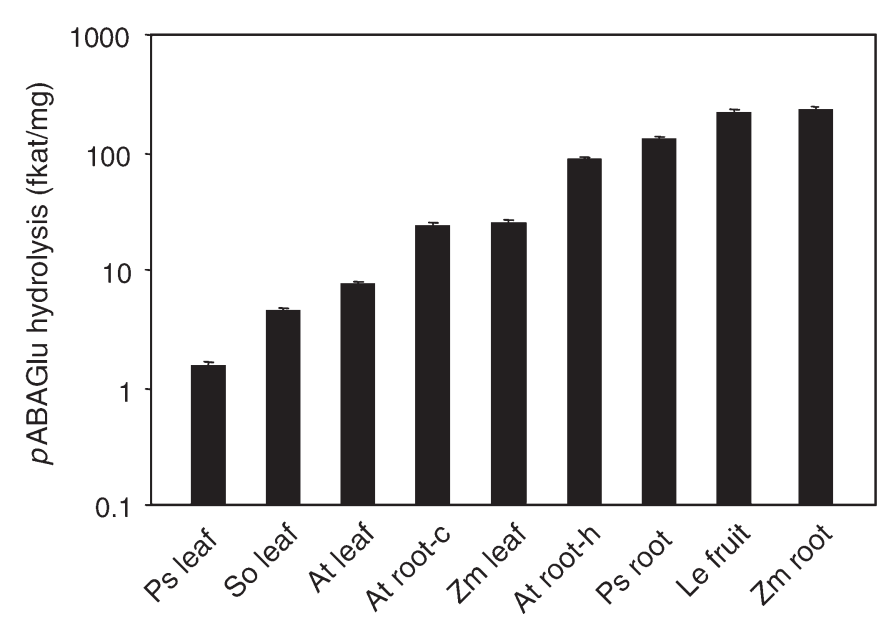

Figure 2. $p A B A G l u$ hydrolase activities in various plant tissues. $\left[{ }^{14} \mathrm{C}\right] p \mathrm{ABA} 7$ production was measured by assay $\mathrm{B}$, with $\left[{ }^{14} \mathrm{C}\right]$ pABAGlu 5 concentration of $18-26 \mu \mathrm{M}$. Pea (Ps), Arabidopsis (At) and maize $(\mathrm{Zm})$ leaves were 9, 28, and 11-days-old, respectively. Pea, maize, Arabidopsis cultured roots (-c) and hydroponic (-h) roots were 10, 6, 23, and 48-days old, respectively. Tomato (Le) pericarp was in the mature green stage. Spinach (So) leaves were fully expanded. Values are the means of three replicates and SE. Note that the scale is logarithmic.

fied chloroplasts and mitochondria were essentially uncontaminated by other fractions (Figure 3). PGH activity was detected in mitochondrial and cytosol plus vacuole fractions, but not in chloroplasts (Figure 3). Multiplying the specific activity of PGH in each fraction by the percentage of cellular protein present in that fraction indicated that $89 \%$ of the cellular activity is in the cytosol plus vacuole fraction (Table 1 ). The PGH activity of vacuolar preparations was not enriched relative to the cytosol/vacuole fraction, although the vacuolar marker a-mannosidase was enriched up to three-fold (not shown). This indicates that PGH is certainly not solely vacuolar but is possibly partially so. In any case, the occurrence of activity in two subcellular fractions signals the presence of at least two PGH isoforms.

\subsection{Chromatographic separation of pABAGlu hydrolase activity}

To further investigate $\mathrm{PGH}$, activity from Arabidopsis leaves and roots was precipitated with $\left(\mathrm{NH}_{4}\right)_{2} \mathrm{SO}_{4}$ and separated by hydrophobic interaction (Octyl-Sepharose) followed by anion exchange (Mono Q) and gel filtration (Superdex 200) steps. The activity from both leaves and roots eluted as one broad peak from Octyl-Sepharose columns (not shown) and also from the Mono $Q$ column, although a shoulder was sometimes evident in the Mono Q peak (Figures 4 \& 5). Subsequent Superdex 200 fractionation yielded a single 200-kDa peak from roots, but three peaks from leaves, with estimated molecular masses of 90, 200, and $360 \mathrm{kDa}$ (Figures 4 \& 5). In some leaf preparations, an additional $40-\mathrm{kDa}$ peak was also present (not shown). While consistent with the existence of various PGH isoforms (i.e., various gene products),
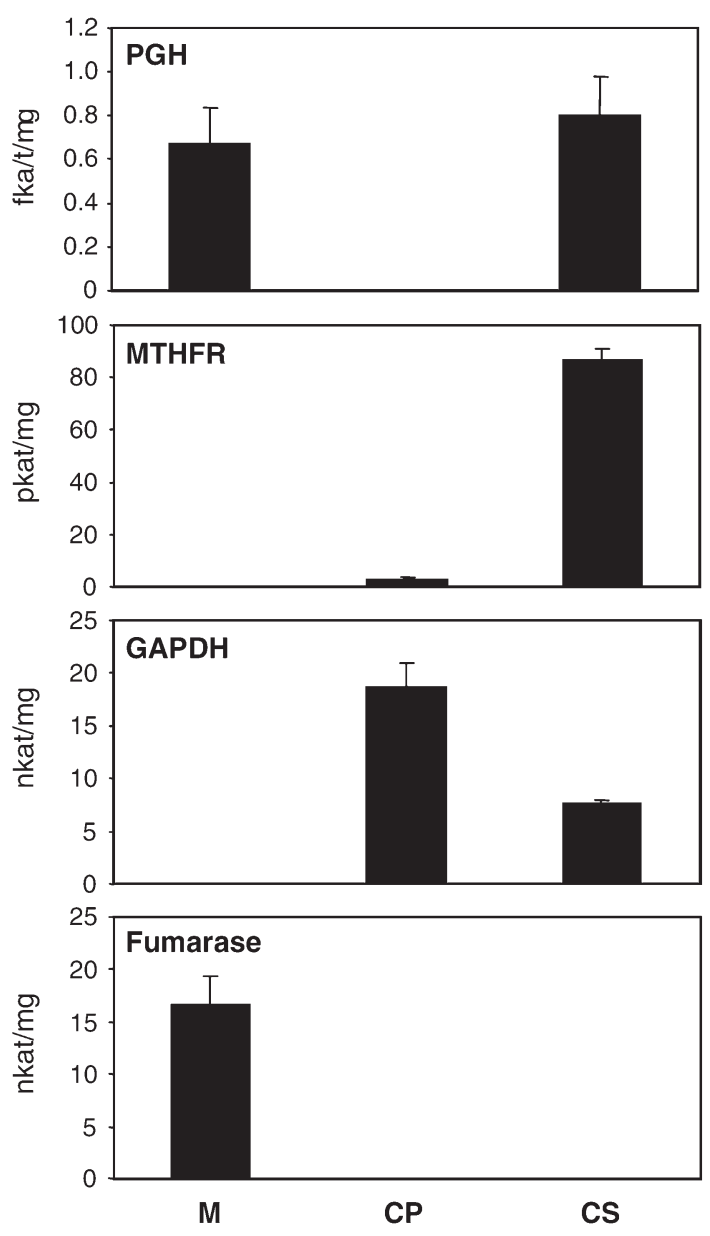

Figure 3. Localization of $p$ ABAGlu hydrolase activity in pea mesophyll cells by subcellular fractionation. Chloroplasts (CP) and mitochondria $(\mathrm{M})$ were purified on Percoll gradients. A fraction enriched in cytosol and vacuole contents (CS) was prepared from pea leaf protoplasts by pelleting intact organelles. The specific activities of PGH and marker enzymes were assayed in each fraction. Markers were: NADP-linked glyceraldehyde-3-phosphate dehydrogenase (GAPDH, chloroplast), fumarase (mitochondrion), and methylenetetrahydrofolate reductase (MTHFR, cytosol). Data are the means and SE of data from three independent preparations of each fraction.

Table 1. Calculated distribution of pABAGlu hydrolase activity among subcellular fractions of pea leaves

\begin{tabular}{lccc}
\hline Fraction & $\begin{array}{l}\text { PGH activity } \\
(\text { fkat } / \mathrm{mg})\end{array}$ & $\begin{array}{l}\text { Protein }^{\mathrm{b}} \\
(\% \text { of cell total })\end{array}$ & $\begin{array}{l}\text { PGH distribution } \\
(\% \text { of cell total })\end{array}$ \\
\hline Cytosol + vacuole & 0.80 & 26 & 89 \\
Mitochondria & 0.67 & 4 & 11 \\
Chloroplasts & 0 & 70 & 0 \\
\hline
\end{tabular}

a. Values taken from Figure 3.

b. Values from Jabrin et al. (2003).

these data could also be explained by oligomerization of a single protein.

Representative purifications from leaves and roots are summarized in Table 2. Overall purification was 268-fold from leaves and 86-fold from roots; activity was generally lost at each column step, and final activity re- 


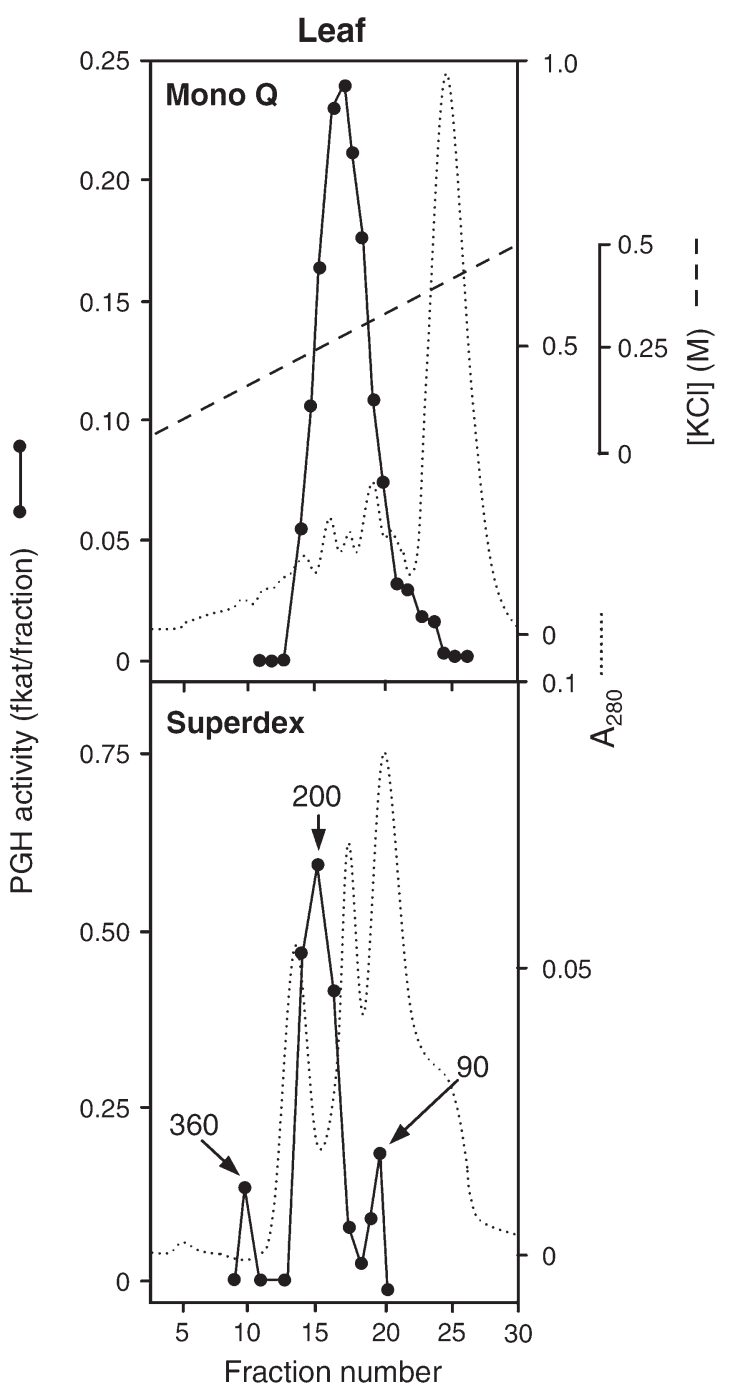

Figure 4. Elution profiles of Arabidopsis leaf pABAGlu hydrolase activity from Mono Q and Superdex 200 columns. After $\left(\mathrm{NH}_{4}\right)_{2} \mathrm{SO}_{4}$ and Octyl-Sepharose steps, activity was applied to a Mono $\mathrm{Q}$ column, whose peak fractions were then applied to the Superdex 200 column. Fraction volumes were $300 \mu \mathrm{L}$ for Mono Q, $320 \mu \mathrm{L}$ for Superdex 200.

coveries were only $4-7 \%$. SDS-PAGE analysis of the final products revealed many protein bands (not shown). Attempts at further purification by dye-affinity chromatography resulted in $\geq 90 \%$ loss of the remaining activity.

PGH enzymes are probably rare proteins, as the following theoretical calculation shows. Taking Arabidopsis PGHs to have the same specific activity as pure CPG (3.6-12 $\mu \mathrm{kat} / \mathrm{mg}$ ) (McCullough et al., 1971; Sherwood et al., 1985) and the activity in cultured roots (Figure 2), extrapolated to $V_{\max }$ (see below), as $\sim 0.4 \mathrm{pkat} / \mathrm{mg}$. then the predicted abundance of PGH proteins is $\leq 1$ in $10^{7}$.

\subsection{Enzymatic properties of root pABAGlu hydrolase}

As roots were richer in PGH activity than leaves (Figure 2) and gave one major peak on Superdex 200, characterization work was done mainly with root PGH using fractions from this peak.

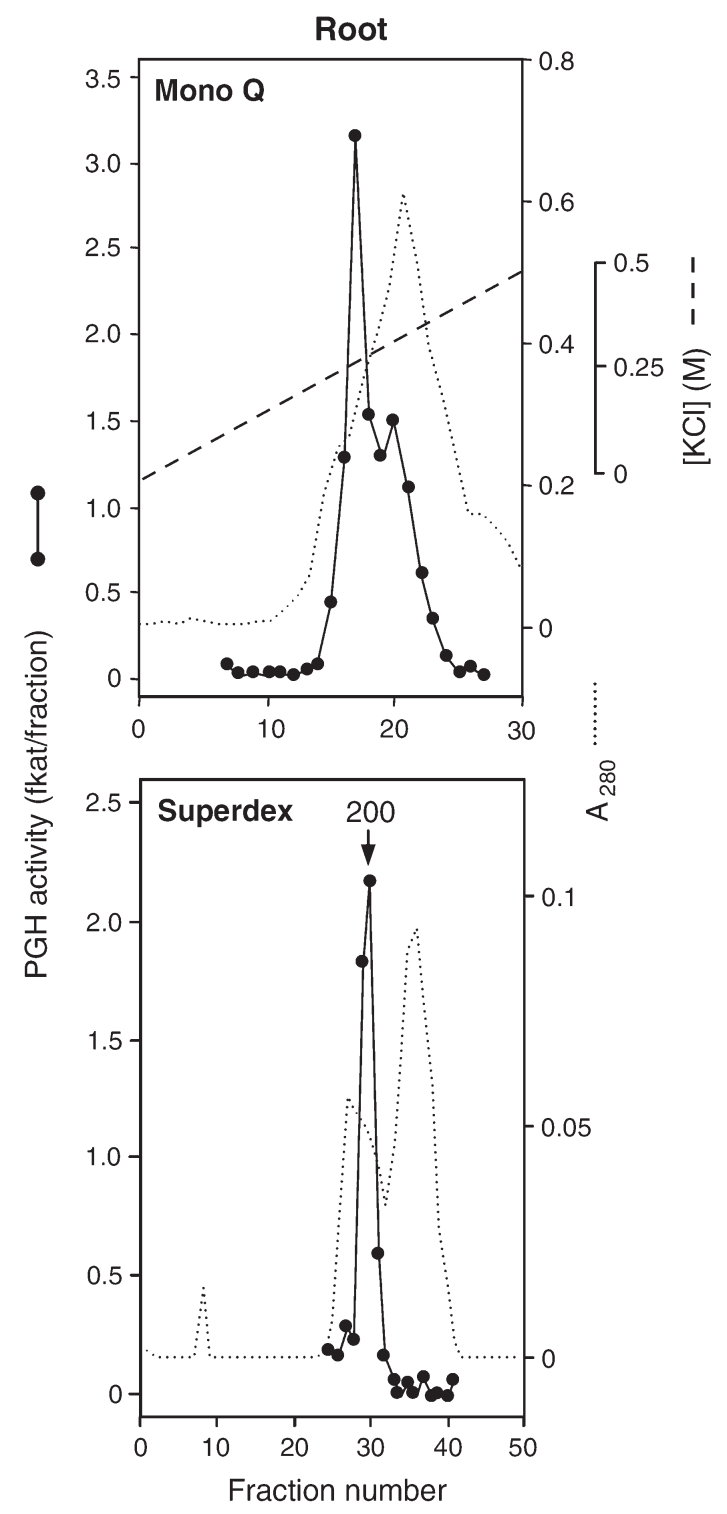

Figure 5. Elution profiles of Arabidopsis root pABAGlu hydrolase activity from Mono Q and Superdex 200 columns. After $\left(\mathrm{NH}_{4}\right)_{2} \mathrm{SO}_{4}$ and Octyl-Sepharose steps, activity was applied to a Mono $Q$ column, whose peak fractions were then applied to the Superdex 200 column. Fraction volumes were $300 \mu \mathrm{L}$ for Mono Q, $400 \mu \mathrm{L}$ for Superdex 200.

Root PGH was optimally active at $\mathrm{pH}$ 7.3-7.5, with half-maximal activity at $\mathrm{pH} 6.5$ and 8.3. Inhibitors were used to test whether the activity is due to a serine-, cysteine-, aspartic-, or metallohydrolase (Table 3). Activity was fairly insensitive to serine, cysteine, and aspartic reagents, but was inhibited totally by one of the metal chelators tested (8-hydroxyquinoline-5-sulfonate) and moderately (53\%) by another (TPEN). Moreover, the root enzyme showed modest but significant stimulation by $0.1 \mathrm{mM} \mathrm{Mn}^{2+}(54 \% ; P<0.05)$ but not by $\mathrm{Zn}^{2+}$ or $\mathrm{Ni}^{2+}$; $\mathrm{Cu}^{2+}$ and $\mathrm{Hg}^{2+}$ abolished activity. Taken together, these data point to a metalloenzyme. Compounds $(1 \mathrm{mM})$ found to have little $(\leq 24 \%)$ effect on activity were ascorbate, glutathione, $\beta$-mercaptoethanol, and ATP (not shown). DTT (1 mM) caused 53\% inhibition. 
Table 2. Purification of $p$ ABAGlu hydrolase from Arabidopsis leaves and roots

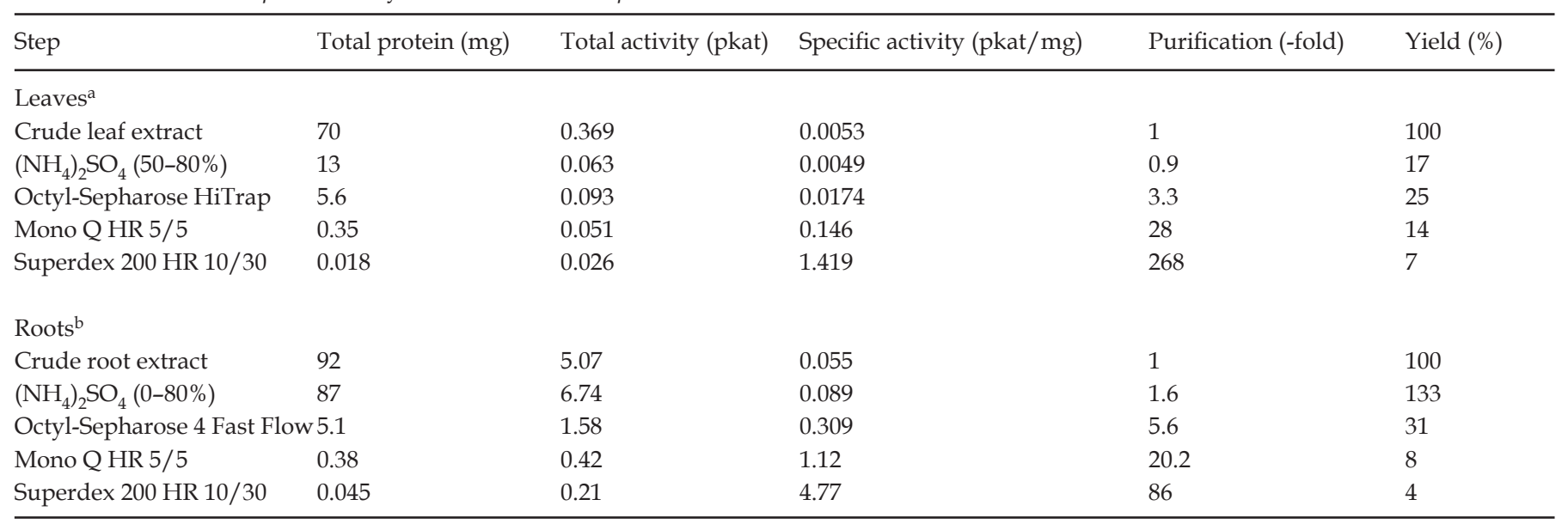

a. About $30 \mathrm{~g}$ of leaves were used. Enzyme activity was measured using assay A and a [3H]pABAGlu concentration of $5 \mu \mathrm{M}$.

b. About $75 \mathrm{~g}$ of roots were used. Enzyme activity was measured using assay B and a $\left[{ }^{14} \mathrm{C}\right] p \mathrm{ABAGlu}$ concentration of $18.2 \mu \mathrm{M}$.

Table 3. Inhibitor sensitivity of $p$ ABAGlu hydrolase from Arabidopsis roots

\begin{tabular}{|c|c|c|}
\hline Inhibitor & Target & $\begin{array}{l}\text { Activity } \\
\text { (\% of control) }\end{array}$ \\
\hline EDTA 1 mM & Metals & 79 \\
\hline 1,10-Phenanthroline $100 \mu \mathrm{M}$ & Metals & 75 \\
\hline TPEN $^{\mathrm{b}} 100 \mu \mathrm{M}$ & Metals & 47 \\
\hline $\begin{array}{l}\text { 8-Hydroxyquinoline-5-sulfonate } \\
1 \mathrm{mM}\end{array}$ & Metals & 0 \\
\hline $\begin{array}{l}\text { Phenylmethylsulfonylfluoride } \\
1 \mathrm{mM}\end{array}$ & Serine, cysteine & 85 \\
\hline $\begin{array}{l}\text { 5,5'-Dithio-bis(2-nitrobenzoic acid) } \\
1 \mathrm{mM}\end{array}$ & Cysteine & 75 \\
\hline Pepstatin $1.5 \mu \mathrm{M}$ & Aspartate & 72 \\
\hline
\end{tabular}

a. Control activity in the absence of inhibitor was 3.6-4.8 pkat/mg, measured at a $\left[{ }^{14} \mathrm{C}\right] p \mathrm{ABAGlu}$ concentration of $18.2-25.9 \mu \mathrm{M}$ using assay B. Values are means of three determinations.

b. $N, N, N^{\prime}, N^{\prime}$-tetrakis[2-pyridylmethyl]ethylenediamine.

The relation between velocity and $p$ ABAGlu concentration was Michaelian for the root enzyme (Figure 6), with an apparent $K_{\mathrm{m}}$ value of $370 \pm 19 \mu \mathrm{M}$ (mean \pm SE of three determinations). Root PGH activity was inhibited by folic acid 1; measured at a $p$ ABAGlu 5 concentration of $19 \mu \mathrm{M}$, the concentration of folic acid 1 giving $50 \%$ inhibition $\left(\mathrm{IC}_{50}\right.$ ) was $52 \pm 8 \mu \mathrm{M}$ (mean $\pm \mathrm{SE}$ of three determinations). In view of this observation, and because CPG cleaves folates as well as pABAGlu 5 (McCullough et al., 1971), we tested folic acid $\mathbf{1}$ as a substrate for the root enzyme preparation, using a TLC radioassay (Oe et al., 1983) similar to that used to measure pABAGlu $\mathbf{5}$ hydrolysis. This assay indicated that folic acid $\mathbf{1}$ was cleaved to pteroate 3 (Figure 7a), which was confirmed by HPLC (Figure 7b). As the root enzyme preparation was not homogeneous, the activity against folic acid $\mathbf{1}$ cannot necessarily be ascribed to the same protein(s) as PGH activity. This is, however, the most economical explanation.

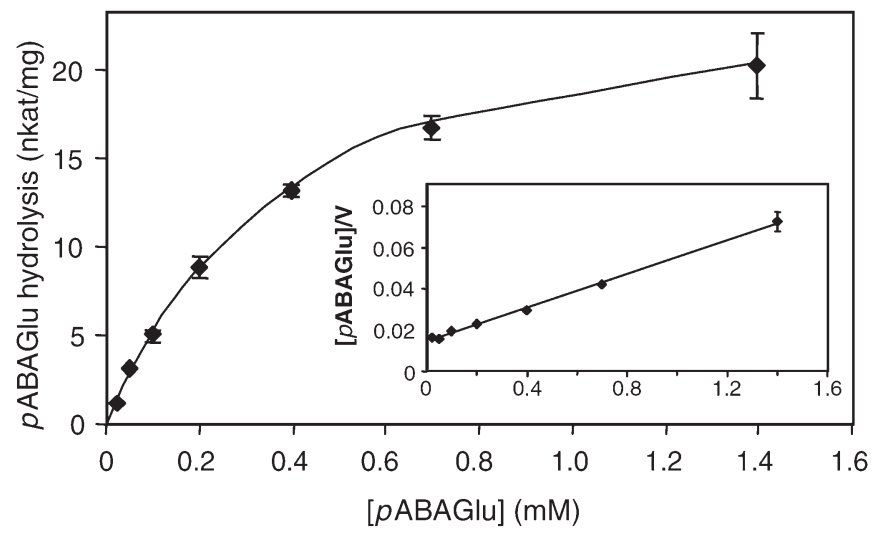

Figure 6. Kinetic analysis of Arabidopsis root $p$ ABAGlu hydrolase activity. Activity was measured using assay A, and various concentrations of $\left[{ }^{14} \mathrm{C}\right] p A B A G l u 5$. Incubation time was $5 \mathrm{~h}$. The main graph is a velocity versus $p$ ABAGlu 5 concentration plot, with mean values $( \pm \mathrm{SE})$ for three independent experiments; the inset is a Hanes plot for the mean data.

\subsection{Carboxypeptidase G-like proteins in Arabidopsis}

The only enzyme certainly known to hydrolyze $p$ ABAGlu 5 is CPG (McCullough et al., 1971) although genetic evidence indicates that the E. coli AbgA and AbgB proteins, which are weakly similar to CPG, also do so (Hussein et al., 1998; Carter et al., 2007). As all three belong to the M20 metallopeptidase family, and our data implicated a metalloenzyme (Table 3), we searched the Arabidopsis genome for similar proteins. CPG, AbgA, and $\mathrm{AbgB}$ sequences gave significant matches only to auxin conjugate hydrolases (LeClere et al., 2002) and to the At4g17830 protein, a putative metallopeptidase. The auxin conjugate hydrolase family of Arabidopsis includes four $\mathrm{Mn}^{2+}$-dependent proteins that cleave indole acetic acid-amino acid conjugates (ILL1, ILL2, ILR1, and IAR3) and two proteins (ILL3 and ILL6) whose substrate is unknown (LeClere et al., 2002). 

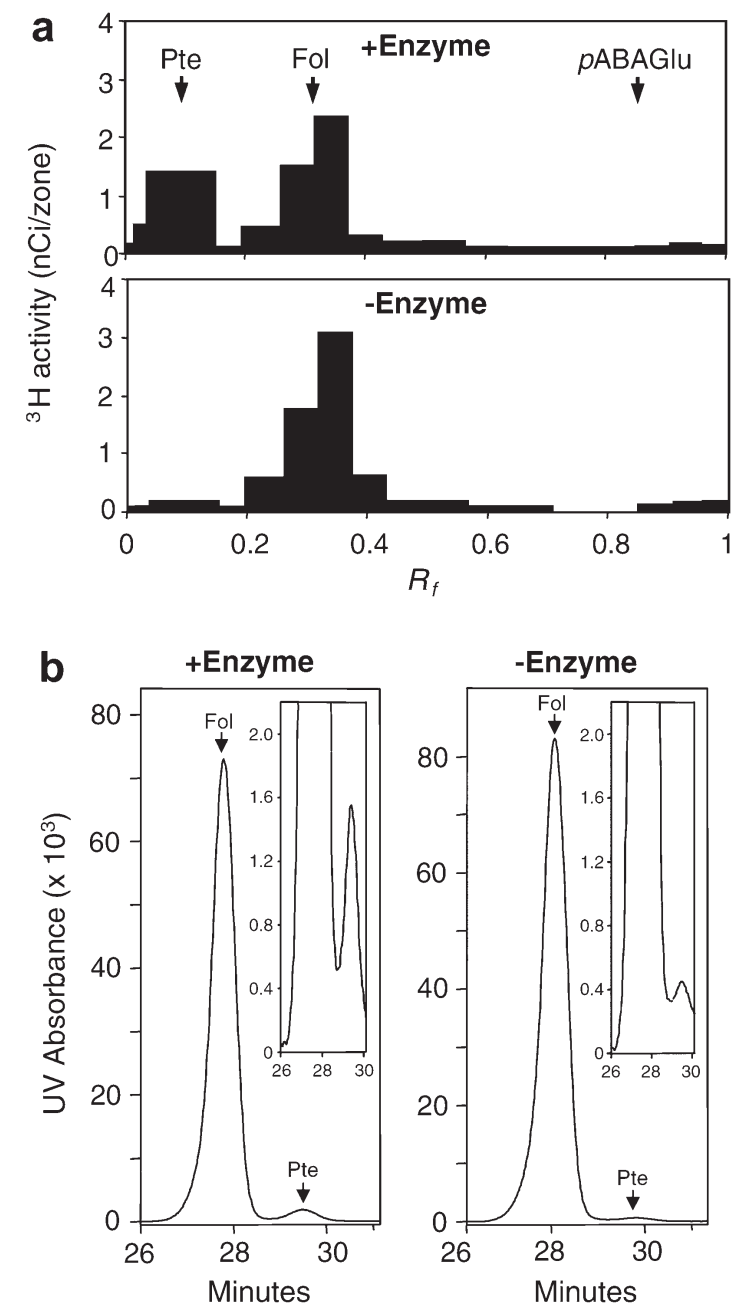

Figure 7. Evidence for folic acid-hydrolyzing activity in the $p$ ABAGlu hydrolase preparation from Arabidopsis roots. (a) TLC separation of radioactivity after incubation of $\left[{ }^{3} \mathrm{H}\right]$ folic acid $1(12 \mathrm{nCi}$, $0.28 \mathrm{pmol}$ ) in $10-\mu \mathrm{L}$ reaction mixtures for $5 \mathrm{~h}$ plus or minus enzyme $(0.7 \mu \mathrm{g})$. Positions of co-chromatographed standards are indicated. Note the absence of label from the $p$ ABAGlu zone; this confirms that only the $p$ ABA-glutamate bond of folic acid was cleaved, not the pterin- $p$ ABA bond. (b) HPLC separation of $10-\mu \mathrm{L}$ reaction mixtures containing $5 \mathrm{nmol}$ of folic acid $\mathbf{1}$ after incubation for $5 \mathrm{~h}$ plus or minus enzyme $(0.18 \mu \mathrm{g})$. The inset shows the pteroate 3 peak on a 25-fold magnified UV absorbance scale. Running positions of standards are indicated.

The six members of the auxin conjugate hydrolase group and the At4g17830 protein were expressed in $E$. coli and tested for PGH activity. The former were expressed as GST fusions and purified using glutathione-agarose columns. At4g17830 was expressed with a hexahistidine tag and purified by $\mathrm{Ni}^{2+}$ affinity chromatography. The IAA-alanine hydrolyzing activities of two of the most efficient auxin conjugate hydrolases - ILL2 and IAR3 - were used as positive controls, and were found to be similar to those previously reported (Davies et al., 1999; LeClere et al., 2002). Although all seven proteins were enriched to near-homogeneity, none of them had significant PGH activity; only ILR1 showed any trace of activity (Figure 8).

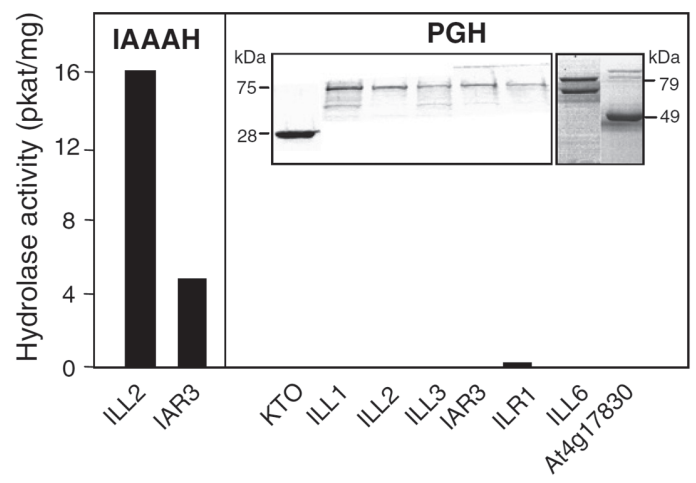

Figure 8. Screening recombinant Arabidopsis CPG-like proteins for PGH activity. The auxin conjugate hydrolase family members were expressed as glutathione $S$-transferase (GST) fusions in pGEX-KTO (KTO); At4g17830 was expressed with a C-terminal histidine tag in pET28b. Enzyme activities were assayed on proteins purified by affinity chromatography. Denaturing gel electrophoresis confirmed the presence of recombinant protein bands (inset) with the expected $M_{\mathrm{r}}$ values (28 kDa for GST; 75-79 kDa for GST-auxin conjugate hydrolase fusions; $49 \mathrm{kDa}$ for At4g17830). PGH activity was measured in the presence of $1 \mathrm{mM} \mathrm{MnCl}_{2}$; results with $1 \mathrm{mM} \mathrm{ZnCl}$, or with no added divalent cations were the same. As positive controls, ILL2 and IAR3 were tested for indole acetic acid-alanine hydrolase (IAAAH) activity in the presence of $1 \mathrm{mM} \mathrm{MnCl}_{2}$. Data are means of duplicate determinations.

\section{Concluding remarks}

Our evidence is consistent with the $p$ ABAGlu hydrolase activity of both pea and Arabidopsis being due to two or more isoforms, at least one of which is a metalloenzyme and all of which are of low abundance. The existence of more than one isoform is presaged by the situation in $E$. coli, in which disrupting $a b g A$ or $a b g B$ does not much affect PGH activity (Hussein et al., 1998).

An obvious approach to identifying plant PGH genes - screening all Arabidopsis homologs of bacterial PGHs for activity - indicated that none of them is a PGH. From this it follows that plant proteins with PGH activity must be novel in the sense either that they are: (a) known enzymes not yet known to attack pABAGlu 5, or (b) proteins whose activity is so far unknown. The former possibility seems likelier, for two reasons. First, pABAGlu 5 has never been tested as a substrate for most peptidases, which are good candidates a priori. Second, the tyrosine- $p \mathrm{ABA}$ bond in the synthetic peptide $N$-benzoyl-Ltyrosyl- $p$ ABA is cleaved by chymotrypsin (Yamato and Kinoshita, 1978). Given the failure of sequence homology to find plant proteins with PGH activity, this task clearly requires an approach that makes no prior assumptions about the nature of the enzymes, such as functional complementation screening in bacteria. The pilot studies of Hussein et al. (1998) on the $a b g A$ and $a b g B$ genes in E. coli suggest that this approach may be feasible.

Lastly, our finding that the enzyme preparation from Arabidopsis roots can cleave folates is not unprecedented inasmuch as CPG is known to do the same thing (McCullough et al., 1971). It nevertheless empha- 
sizes an often-overlooked possibility, namely that folate breakdown is in part enzymatic - and hence subject to regulation - as well as merely chemical (Suh et al., 2001).

\section{Experimental}

\subsection{Reagents}

[Ring $\left.{ }^{14} \mathrm{C}\right] p \mathrm{ABA} 7(55 \mathrm{mCi} / \mathrm{mmol}),\left[3,5-{ }^{3} \mathrm{H}\right] p \mathrm{ABA} 7(26.2$ $\mathrm{Ci} / \mathrm{mmol})$ and $\left[3^{\prime}, 5^{\prime}, 7,9-{ }^{3} \mathrm{H}\right]$ folic acid 1 (43.2 Ci/mmol) were from Moravek Biochemicals (Brea, CA, USA). $\left[{ }^{14} \mathrm{C}\right]$ pABAGlu 5 and $\left[{ }^{3} \mathrm{H}\right] p$ ABAGlu 5 were prepared as described (Orsomando et al., 2006). [ $\left.{ }^{3} \mathrm{H}\right]$ Folic acid 1 was purified before use by folate affinity chromatography (Gregory and Toth, 1988). All protein chromatography columns were from GE Healthcare (Piscataway, NJ, USA).

\subsection{Plant material}

Arabidopsis thaliana (L.) Heynh. ecotype Columbia plants for leaf production were grown at $23-28^{\circ} \mathrm{C}$ in 12 -h days

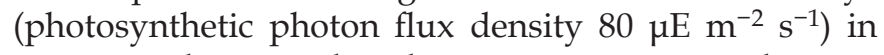
potting soil irrigated with water. For root production, plants were grown hydroponically as described (Gibeaut et al., 1997). Arabidopsis plantlets were cultured axenically in $0.5 \times$ liquid MS salts containing $10 \mathrm{~g} / \mathrm{L} \mathrm{su}-$ crose (Prabhu et al., 1996). Tomato Lycopersicon esculentum (cv. Micro-Tom) and pea (Pisum sativum) (cv. Laxton's Progress 9), plants were grown as described (Díaz de la Garza et al., 2004; Orsomando et al., 2005). Maize (Zea mays cv. NK508) leaves were from 11-day old plants grown in potting soil in a naturally lit greenhouse. Spinach (Spinacia oleracea) was purchased locally.

\subsection{Subcellular fractionation of pea leaves}

Mitochondria and chloroplasts were purified on Percoll gradients (Cline, 1986; Douce et al., 1987). A fraction enriched in cytosol plus vacuole contents, and vacuoles, were prepared from protoplasts (Orsomando et al., 2005). Protoplasts were purified on a three-step sucrose-sorbitol gradient as described (Baldet et al., 1993; Orsomando et al., 2005) except that the middle and bottom layer densities were increased by adding $4 \%$ and $13 \%$ (v/v) Percoll, respectively. Fractions were supplemented with bovine albumin $(1 \mathrm{mg} / \mathrm{mL})$ and concentrated 6- to 13-fold before PGH assays. Marker enzymes were extracted and assayed as described (Orsomando et al., 2005).

\subsection{Hydrolase assays}

For $p$ ABAGlu hydrolase, standard reaction mixtures (final volume $10 \mu \mathrm{L}$ ) contained $8 \mu \mathrm{L}$ of KPi buffer, $50 \mathrm{mM}$, $\mathrm{pH} 7.4$ or $8.0,0.1-16 \mu \mathrm{g}$ protein), $1 \mathrm{mM} \mathrm{MnCl}_{2}$, and either $10-14 \mathrm{nCi}(182-259 \mathrm{pmol})$ of $\left[{ }^{14} \mathrm{C}\right] p A B A G l u ~ 5$ or $42-$ $166 \mathrm{nCi}(70-280 \mathrm{pmol})$ of $\left[{ }^{3} \mathrm{H}\right] p \mathrm{ABAGlu} 5$. Incubation was for $3-8 \mathrm{~h}$ at $30{ }^{\circ} \mathrm{C}$. $\left[{ }^{14} \mathrm{C}\right] p \mathrm{ABA} 7$ was separated either by EtOAc partitioning (Orsomando et al., 2006) (assay A) or by TLC (assay B). $\left.{ }^{3} \mathrm{H}\right] p$ ABA 7 was separated by the former procedure. In the latter, reactions were mixed with unlabeled pABA 7 and pABAGlu 5 carriers $(100 \mathrm{nmol}$ each) and applied to 1-cm origins on 10-cm silica gel 60 $\mathrm{F}_{254}$ TLC plates (Merck, Darmstadt, Germany). After developing with EtOAc: $\mathrm{MeOH}: \mathrm{H}_{2} \mathrm{O}$ (77:13:10, v/v/v), the $p \mathrm{ABA}$ zone $\left(R_{\mathrm{f}} 0.9\right)$ was scraped out for scintillation counting. $\left[{ }^{14} \mathrm{C}\right] p \mathrm{ABA} 7$ formation was linear with respect to time and amount of enzyme. Routine assays in this study used a subsaturating $\left[{ }^{14} \mathrm{C}\right] p \mathrm{ABAGlu} 5$ concentration, 4.5-fold less than that used previously (Orsomando et al., 2006); the activity values reported are consequently lower. Folate hydrolase activity was assayed by a TLC method (Oe et al., 1983) similar to assay B, using $\left[{ }^{3} \mathrm{H}\right]$ folic acid $\mathbf{1}$ as substrate and quantifying pteroate release. The identity of pteroate 3 was confirmed by HPLC with UV detection (300 nm) essentially as described (Díaz de la Garza et al., 2004). Apparent $K_{\mathrm{m}}$ values were determined from Hanes plots (Figure 6).

\subsection{Protein extraction and purification}

All steps were at $0-4{ }^{\circ} \mathrm{C}$. Protein was estimated by the dye-binding method (Bradford, 1976). For tests of PGH activity in various plant sources, proteins were extracted and desalted as described (Orsomando et al., 2006). For protein purification, leaves from seven-week old Arabidopsis plants or roots from 25- to 28-day-old cultures were triturated in liquid $\mathrm{N}_{2}$ and suspended $(1 \mathrm{~g} / 2.5 \mathrm{~mL})$ in $50 \mathrm{mM} \mathrm{KPi}$, pH 8.0 containing 3\% (w/v) polyvinylpolypyrrolidone. The brei was centrifuged $(12,000 g, 20$ $\mathrm{min}$ ) and filtered through Miracloth, with proteins fractionated by adding finely ground $\left(\mathrm{NH}_{4}\right)_{2} \mathrm{SO}_{4}$ to obtain the desired concentration (Table 2). After stirring for 30 min and centrifuging $(13,000 \mathrm{~g}, 20 \mathrm{~min})$, the pellet was redissolved in $20 \mathrm{~mL}$ of $50 \mathrm{mM} \mathrm{KPi}, \mathrm{pH} 8.0,30 \%$ saturated with $\left(\mathrm{NH}_{4}\right)_{2} \mathrm{SO}_{4}$ (Buffer A).

For root proteins, the solution was applied to a $1.3 \times$ $5.6 \mathrm{~cm}$ Octyl Sepharose 4 Fast Flow column equilibrated with Buffer A. The column was washed with Buffer A $(2.5 \mathrm{~mL} / \mathrm{min})$ until the $A_{280}$ of the effluent was $<0.02$. PGH activity was eluted $(2.0 \mathrm{~mL} / \mathrm{min})$ with an $83.5-\mathrm{mL}$ linear gradient (100-0\% Buffer A/0-100\% KPi 50 mM, $\mathrm{pH} 8.0$ ), collecting $2.5-\mathrm{mL}$ fractions. Fractions with activity were pooled and desalted on PD-10 columns equilibrated with $50 \mathrm{mM} \mathrm{KPi}, \mathrm{pH}$ 8.0. For leaf proteins, two $0.7 \times 2.5 \mathrm{~cm}$ Octyl-Sepharose HiTrap columns were coupled and replaced the Fast Flow column.

Active fractions from the Octyl Sepharose step were loaded $(0.5 \mathrm{~mL} / \mathrm{min})$ onto a Mono Q HR 5/5 column equilibrated with $50 \mathrm{mM} \mathrm{KPi}, \mathrm{pH} 8.0$, and the column was washed with this buffer until the $A_{280}$ of the effluent fell to zero. PGH activity was eluted $(0.5 \mathrm{~mL} / \mathrm{min})$ with a 9-mL linear gradient of $0-0.5 \mathrm{M} \mathrm{KCl}$ in $50 \mathrm{mM}$ $\mathrm{KPi}, \mathrm{pH} 8.0$, collecting $0.3-\mathrm{mL}$ fractions. Active fractions 
were pooled and concentrated to $0.5 \mathrm{~mL}$ in a Centricon-10 (Millipore, Billerica, MA, USA).

The concentrate from the Mono Q step was applied $(0.25 \mathrm{~mL} / \mathrm{min})$ to a Superdex $200 \mathrm{HR}$ 10/30 column equilibrated with $50 \mathrm{mM} \mathrm{KPi}$, pH 8.0 containing $50 \mathrm{mM}$ $\mathrm{KCl}$, and eluted with the same buffer, collecting 0.4$\mathrm{mL}$ fractions. From roots, fractions making up the PGH activity peak were pooled, concentrated to $0.28 \mathrm{~mL}$, brought to $10 \%(\mathrm{v} / \mathrm{v})$ glycerol, frozen in liquid $\mathrm{N}_{2}$, and stored at $-80{ }^{\circ} \mathrm{C}$ until use. To estimate native $M_{\mathrm{r}^{\prime}}$ the Superdex column was calibrated with carbonic anhydrase $(29 \mathrm{kDa})$, bovine albumin $(66 \mathrm{kDa})$, alcohol dehydrogenase $(150 \mathrm{kDa})$, a-amylase $(200 \mathrm{kDa})$, apoferritin $(443$ $\mathrm{kDa})$, and bovine thyroglobulin $(669 \mathrm{kDa})$.

\subsection{Recombinant protein expression and purification}

Constructs of cDNAs of the Arabidopsis auxin-conjugate hydrolase family (ILL1, ILL2, ILL3, ILL6, ILR1, and IAR3) in pGEX-KTO (Davies et al., 1999; LeClere et al., 2002) were from B. Bartel and R. Rampey (Rice University, Houston, TX, USA). pGEX-KTO is an expression vector in which the cloned protein is fused to the C-terminus of glutathione S-transferase. The At4g17830 cDNA (obtained from the Arabidopsis Biological Resource Center, OH, USA) was modified by using splice overlap extension PCR to ablate an internal NcoI site, and the modified At4g17830 cDNA was cloned between the NcoI and XhoI sites of pET28b (Novagen), which adds a C-terminal hexahistidine tag. Constructs were introduced into E. coli BL21-CodonPlus (DE3)-RIL cells (Stratagene), which were grown at $37^{\circ} \mathrm{C}$ in LB medium until $A_{600}$ reached 0.6. Temperature was then dropped to $25{ }^{\circ} \mathrm{C}$ and isopropyl-D-thiogalactopyransoside was added (final concentration $0.1 \mathrm{mM}$ ). Incubation was continued for $3 \mathrm{~h}$ at the same temperature. Subsequent procedures were at $0-4{ }^{\circ} \mathrm{C}$. Cells from $50-\mathrm{mL}$ cultures were pelleted, resuspended in $2 \mathrm{~mL}$ of $50 \mathrm{mM}$ Tris- $\mathrm{HCl}$, $\mathrm{pH}$ 8.0, $0.1 \mathrm{mM} \mathrm{MnCl}{ }_{2}, 0.01 \mathrm{mM} \mathrm{ZnCl}{ }_{2}$, and broken in a Mini-BeadBeater (Biospec, Bartlesville, OK, USA). Lysates were cleared by centrifugation $(10,000 \mathrm{~g}, 10 \mathrm{~min})$, desalted on PD10 columns equilibrated with $140 \mathrm{mM}$ $\mathrm{NaCl}, 2.7 \mathrm{mM} \mathrm{KCl}, 10 \mathrm{mM} \mathrm{Na}_{2} \mathrm{HPO}_{4}, 1.8 \mathrm{mM} \mathrm{KH}_{2} \mathrm{PO}_{4}$, $\mathrm{pH}$ 7.3. GST-fusion proteins were purified on GSH-agarose resin and the histidine-tagged protein on Ni-NTA agarose resin (Qiagen, Valencia, CA, USA) according to the manufacturers' recommendations. For extracts of cells expressing ILL2 or IAR3, hydrolysis of indole acetic acid-alanine was measured as described (LeClere et al., 2002).

Acknowledgments - This work was supported in part by National Science Foundation Grant No. MCB-0443709 and by an endowment from the C. V. Griffin, Sr. Foundation. We thank Bonnie Bartel and Rebekah Rampey for auxin conjugate hydrolase cDNA expression constructs and for advice.

\section{References}

- A. M. Albrecht, E. Boldizsar and D. J. Hutchison, Carboxypeptidase displaying differential velocity in hydrolysis of methotrexate, 5-methyltetrahydrofolic acid, and leucovorin. J. Bacteriol., 134 (1978), pp. 506-513.

Baldet et al., $1993 \rightarrow$ P. Baldet, C. Alban, S. Axiotis and R. Douce, Localization of free and bound biotin in cells from green pea leaves. Arch. Biochem. Biophys., 303 (1993), pp. 67-73.

Bradford, 1976 M. M. Bradford, A rapid and sensitive method for the quantitation of microgram quantities of protein utilizing the principle of protein-dye binding. Anal. Biochem., 72 (1976), pp. 248-254.

Carter et al., 2007 E. L. Carter, L. Jager, L. Gardner, C. C. Hall, S. Willis and J. M. Green, Escherichia coli abg genes enable uptake and cleavage of the folate catabolite $p$-aminobenzoyl-glutamate. J. Bacteriol., 189 (2007), pp. 3329-3334.

Chen et al., 1997 L. Chen, S. Y. Chan and E. A. Cossins, Distribution of folate derivatives and enzymes for synthesis of 10-formyltetrahydrofolate in cytosolic and mitochondrial fractions of pea leaves. Plant Physiol., 115 (1997), pp. 299-309.

Cline, $1986-$ K. Cline, Import of proteins into chloroplasts. Membrane integration of a thylakoid precursor protein reconstituted into chloroplast lysates. J. Biol. Chem., 261 (1986), pp. 14804-14810.

Cossins, 2000 E. A. Cossins, The fascinating world of folate and one-carbon metabolism. Can. J. Bot., 78 (2000), pp. 691-708.

Davies et al., 1999 R. T. Davies, D. H. Goetz, J. Lasswell, M. N. Anderson and B. Bartel, IAR3 encodes an auxin conjugate hydrolase from Arabidopsis. Plant Cell, 11 (1999), pp. 365-376.

Díaz de la Garza et al., 2004 R. Díaz de la Garza, E. P. Quinlivan, S. M. Klaus, G. J. Basset, J. F. Gregory and A. D. Hanson, Folate biofortification in tomatoes by engineering the pteridine branch of folate synthesis. Proc. Natl. Acad. Sci. USA, 101 (2004), pp. 13720-13725.

Douce et al., $1987-$ R. Douce, J. Bourguignon, R. Brouquisse and M. Neuburger, Isolation of plant mitochondria. General principles and criteria of integrity. Methods Enzymol., 148 (1987), pp. 403-415.

Gibeaut et al., 1997 D. M. Gibeaut, J. Hulett, G. R. Cramer and J. R. Seemann, Maximal biomass of Arabidopsis thaliana using a simple, low-maintenance hydroponic method and favorable environmental conditions. Plant Physiol., 115 (1997), pp. 317-319.

Gregory and Toth, 1988 J. F. Gregory and J. P. Toth, Chemical synthesis of deuterated folate monoglutamate and in vivo assessment of urinary excretion of deuterated folates in man. Anal. Biochem., 170 (1988), pp. 94-104.

Hussein et al., $1998-$ M. J. Hussein, J. M. Green and B. P. Nichols, Characterization of mutations that allow $p$-aminobenzoyl-glutamate utilization by Escherichia coli. J. Bacteriol., 180 (1998), pp. 6260-6268. 
Jabrin et al., $2003 \rightarrow$ S. Jabrin, S. Ravanel, B. Gambonnet, R. Douce and F. Rébeillé, One carbon metabolism in plants. Regulation of tetrahydrofolate synthesis during germination and seedling development. Plant Physiol., 131 (2003), pp. 1431-1439.

LeClere et al., 2002 S. LeClere, R. Tellez, R. A. Rampey, S. P. T. Matsuda and B. Bartel, Characterization of a family of IAA-amino acid conjugate hydrolases from Arabidopsis. J. Biol. Chem., 277 (2002), pp. 20446-20452.

McCullough et al., 1971 J. L. McCullough, B. A. Chabner and J. R. Bertino, Purification and properties of carboxypeptidase G1. J. Biol. Chem., 246 (1971), pp. 7207-7213.

Minton et al., $1983 \rightarrow$ N. P. Minton, T. Atkinson and R. F. Sherwood, Molecular cloning of the Pseudomonas carboxypeptidase G2 gene and its expression in Escherichia coli and Pseudomonas putida. J. Bacteriol., 156 (1983), pp. 1222-1227.

Oe et al., 1983 H. Oe, M. Kohashi and K. Iwai, Radioassay of the folate-hydrolyzing enzyme activity, and the distribution of the enzyme in biological cells and tissues. J. Nutr. Sci. Vitaminol. (Tokyo), 29 (1983), pp. 523-531.

Orsomando et al., 2005 G. Orsomando, R. Díaz de la Garza, B. J. Green, M. Peng, P. A. Rea, T. J. Ryan, J. F. Gregory and A. D. Hanson, Plant ( $\gamma$-glutamyl hydrolases and folate polyglutamates: characterization, compartmentation, and co-occurrence in vacuoles. J. Biol. Chem., 280 (2005), pp. 28877-28884.
Orsomando et al., 2006 G. Orsomando, G. G. Bozzo, R. Díaz de la Garza, G. J. Basset, E. P. Quinlivan, V. Naponelli, F. Rébeillé, S. Ravanel, J. F. Gregory and A. D. Hanson, Evidence for folate-salvage reactions in plants. Plant J., 46 (2006), pp. 426-435.

Prabhu et al., $1996>$ V. Prabhu, K. B. Chatson, G. D. Abrams and J. King, 13C Nuclear magnetic resonance detection of interactions of serine hydroxymethyltransferase with C1tetrahydrofolate synthase and glycine decarboxylase complex activities in Arabidopsis. Plant Physiol., 112 (1996), pp. 207-216.

Scott et al., $2000-$ J. Scott, F. Rébeillé and J. Fletcher, Folic acid and folates: the feasibility of nutritional enhancement in plant foods. J. Sci. Food Agric., 80 (2000), pp. 795-824.

Sherwood et al., $1985 \rightarrow$ R. F. Sherwood, R. G. Melton, S. M. Alwan and P. Hughes, Purification and properties of carboxypeptidase G2 from Pseudomonas sp. Strain RS-16. Eur. J. Biochem., 148 (1985), pp. 447-453.

Suh et al., 2001 J. R. Suh, A. K. Herbig and P. J. Stover, New perspectives on folate catabolism. Annu. Rev. Nutr., 21 (2001), pp. 255-282.

Yamato and Kinoshita, 1978 C. Yamato and K. Kinoshita, Hydrolysis and metabolism of N-benzoyl-L-tyrosyl-p-aminobenzoic acid in normal and pancreatic duct-ligated animals. J. Pharmacol. Exp. Ther., 206 (1978), pp. 468-474. 